2. To: (Receiving Organization)

Evaporator Project

5. Proj./Prog./Dept./Div.:

AW Ventilation Upgrade/N2169

8. Originator Remerks:

ETN 95-0031

11. Receiver Remarks:
3. From: (originating organization)

TWRS Equipment Engineering

6. Cog. Engr.:

D.J. Minteer
4. Related EDT No.:

N/A

7. Purchase Order No.:

N/A

9. Equip./Component No.:

N/A

10. System/Bldo./Facility:

241-AW

12. Mejor Assm. Dwg. Mo.:

$\mathrm{H}-2-85614$

13. Permit/Pernit Applicetion Mo.: $N / A$

14. Required Response Date:

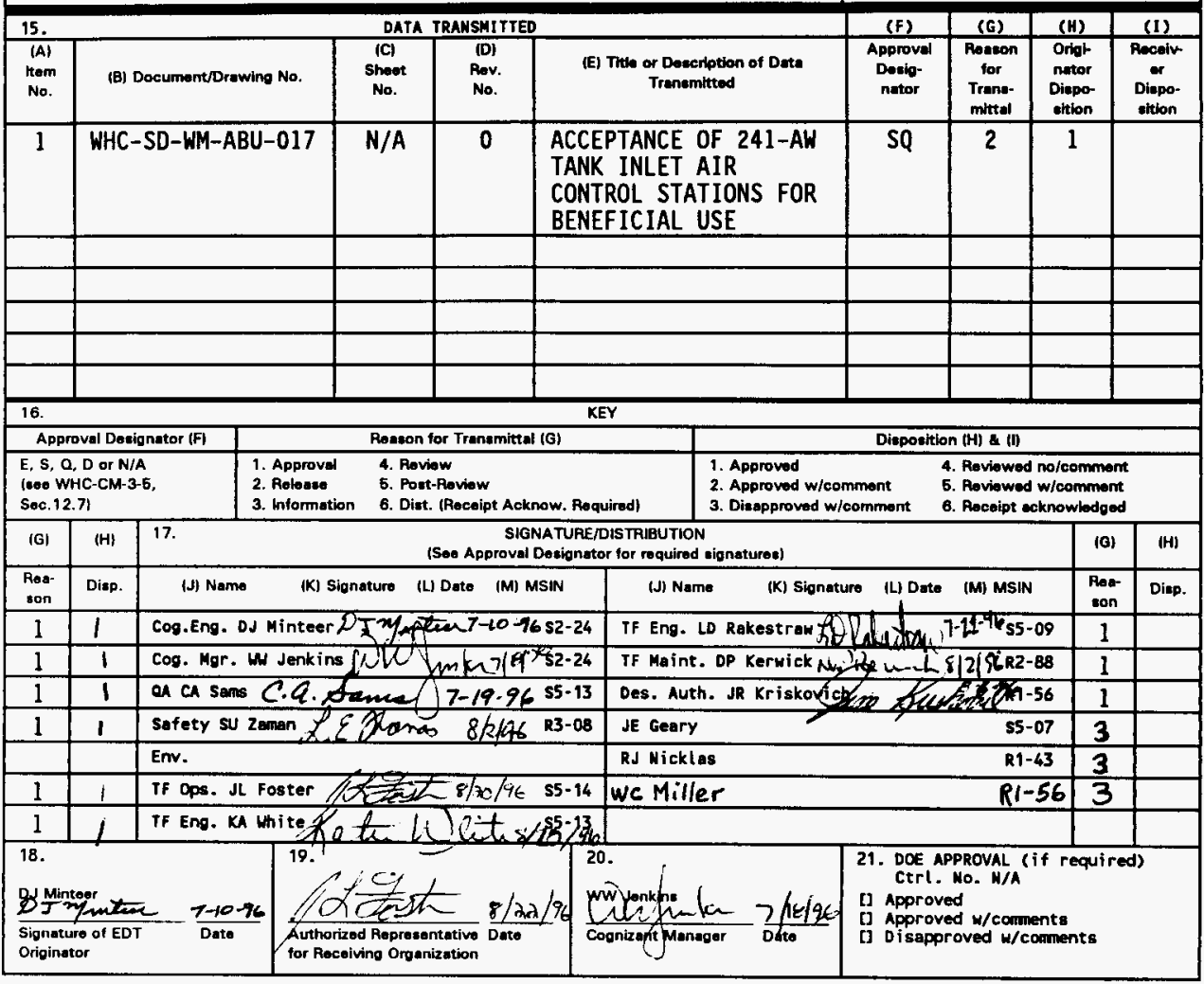




\title{
ACCEPTANCE OF 241-AW TANK INLET AIR CONTROL STATIONS FOR BENEFICIAL USE
}

\section{Daniel J Minteer}

West inghouse Hanford Company, Richland, WA 99352

U.S. Department of Energy Contract DE-AC06-87RL10930

\author{
EDT/ECN: 613031 \\ UC: \\ Org Code: 74F10 \\ Charge Code: N2169 \\ B\&R Code: \\ Total Pages: 12
}

Key Words: AW, VENT, FILTER, ABU, TURNOVER

Abstract: This document provides reference to the Acceptance for Beneficial Use (ABU) documentation and effects turnover of the AW tank inlet air control stations from TWRS Equipment Engineering to Evaporator Project.

IRADEMARK DISCLAIMER. Reference herein to any specific commercial product, process, or service by trade nane, tradenark, manufacturer, or otherwise, does not necessarily consti tute or imply its endorsement, recommendation, or favoring by the United states Govermment or any agency thereof or its contractors or subcontractors.

Printed in the United states of America. To obtain copies of this document, contact: WHC/BCS Document Control services, P.0. Box 1970, Mailstop H6-08, Richland wh 99352, Phone (509) 372-2420; Fax (509) 376-4989.
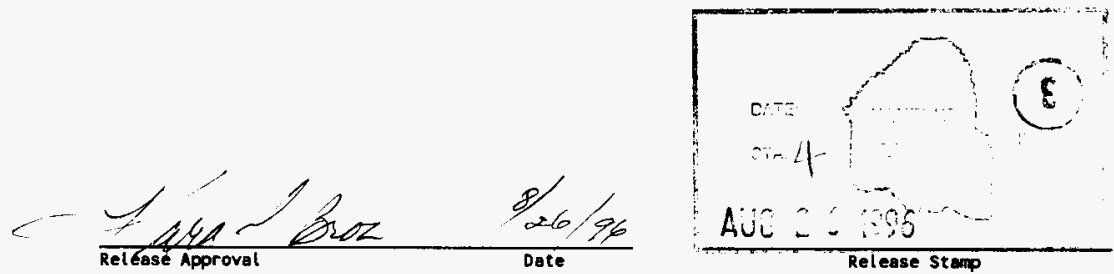

\section{Approved for Public Release}


WHC-SD-WM-ABU-017

Rev 0

Page 1

ACCEPTANCE OF 241-AW TANK INLET AIR CONTROL STATIONS FOR BENEFICIAL USE

July 8, 1996

Author

D.J. Minteer 
WHC-SD-WM-ABU-017

Rev 0

Page 2

Table of Contents

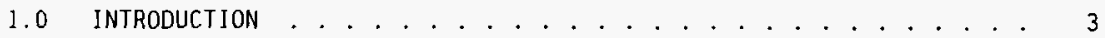

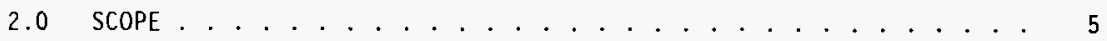

3.0 ACCEPTANCE FOR BENEFICIAL USE DOCUMENTATION .......... 5

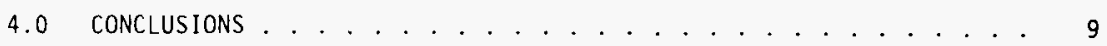

FigURE 1 - TANK INLET Air CONTROL STATION . . . . . . . . . . 4

APPENDIX A - ACCEPTANCE FOR BENEFICIAL USE CHECKLIST . . . . . . . 10 


\subsection{INTRODUCTION}

Flammable gas is continually produced in most of the Hanford radioactive waste tanks. There are six such tanks in the 241-AW tank farm. In addition, two of the AW tanks (101 and 104) exhibit the characteristics and tendency to store and suddenly release larger quantities of gas. Waste tank ventilation is necessary to, among other things, prevent flammable gas build up in the tank vapor spaces and reduce flammable gas concentrations as quickly as possible after a sudden gas release.

The AW primary waste tanks are ventilated by a common exhaust system. The system was not originally designed to allow adequate control of individual tank flow rates. Air would enter each tank primarily through penetrations in the pump and valve pit cover blocks (valve handles, cover plates, seams, edge cracks) and then through the leaking, misaligned, or removed pit drain plugs and/or other pit apertures. Metalized tape used on the cover block edges/seams was virtually the only "hardware" which could offer a means of proportioning tank air flows. Balancing air flow in this manner, however, would be laborious and ineffectual considering that work activities and/or weather could quickly negate the efforts.

A tank inlet air control station was installed on each 24l-AW primary tank in January 1996. Acceptance testing was completed in February 1996. On March 21, 1996 the Operational Test Procedure was performed and all six units were subsequently placed into service. The air control stations, intended to be the primary air paths into the waste tanks, provide a new capability for maintaining an easily set and verifiable air flow rate into each waste tank. The air control stations can also be used to manipulate tank vacuum levels. In addition, each station acts as a filtered, pressure relief for the tank air space. See Figure 1 .

Each station is designed to accommodate flow rates up to $500 \mathrm{scfm}$, which, times six tanks, exceeds the capabilities of the current ventilation system. Primary components of each air control station include, in order of inward flow, an air flow controller (keeps flow constant, indicates whether the known set flow is occurring, and defaults to its open position during a flow reversal), a pre-filter, a HEPA filter (to reduce the consequences of air flow reversals should tank pressures exceed atmospheric pressure due to loss of active ventilation or a large gas release from the waste), and a 12" isolation butterfly valve (normally open). Differential pressure gages are provided to support evaluation of filter condition. A vacuum breaker is connected in parallel with the flow controller to iimit tank vacuum in 
WHC-SD-WM-ABU-017

Rev 0

Page 4

FIGURE 1 - TANK INLET AIR CONTROL STATION

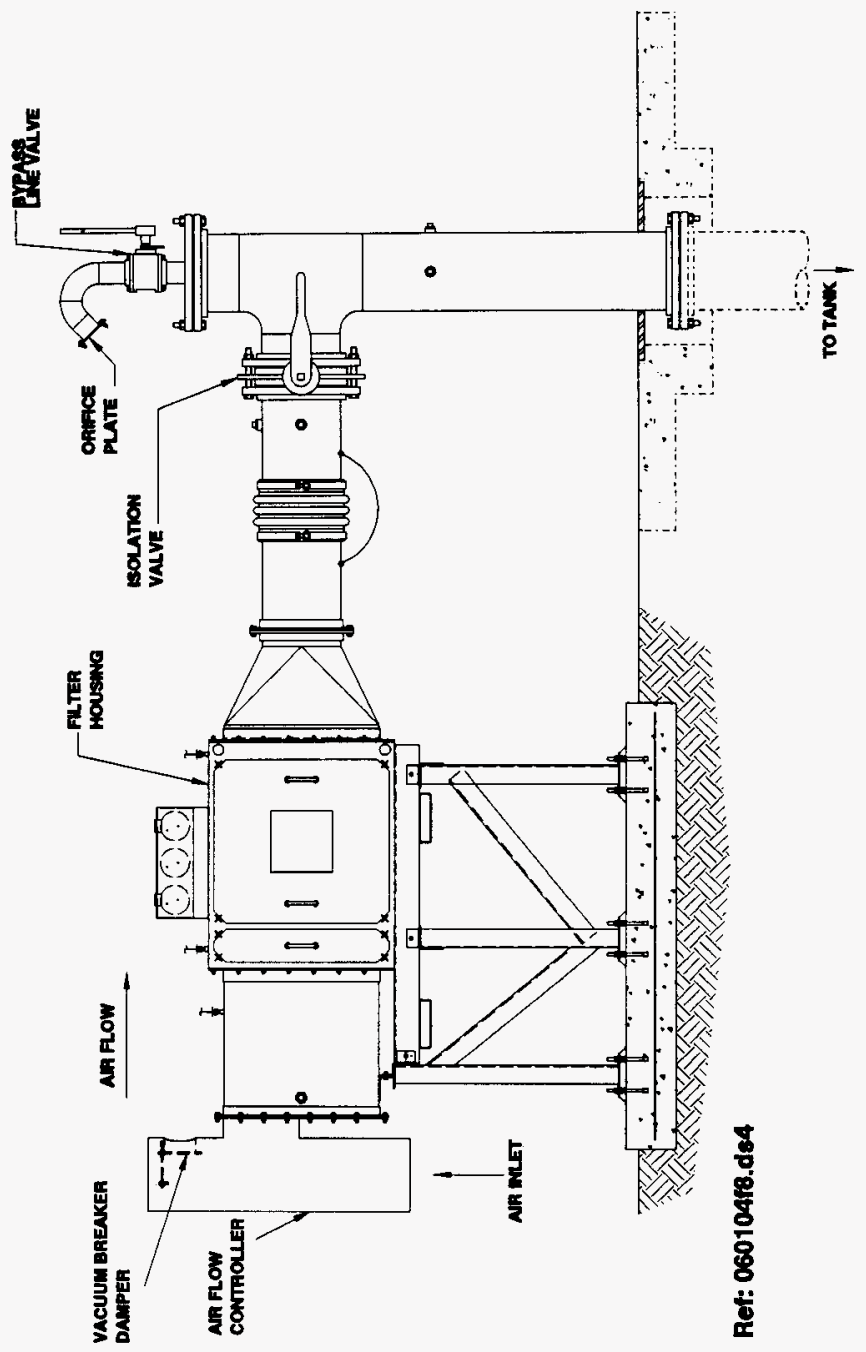


the event that the flow control capability is lost. The air flow controller and vacuum breaker are system-operated devices, requiring no electrical power or control instrumentation. An alternate tank air inlet line, or bypass line, containing an orifice plate and isolation valve (normally closed) is connected in parallel with each air control station for use during station maintenance or in the event that the normal air path through the air control station becomes obstructed.

\section{$2.0 \quad$ SCOPE}

This document provides reference to the documentation required for Acceptance for Beneficial Use (ABU) which was identified in WHC-SD-WMETP-141, Engineering Task Plan for 24I-AW Ventilation Improvements, Rev 1 (the ABU checklist is provided herein as Appendix A). Any deviations from the $A B U$ checklist are noted in Section 3.0 and are accepted by approval of this document.

Approval of this document indicates agreement that the ABU documentation listed in Section 3.0 is sufficient to effect official turnover of the AW tank inlet air control stations from TWRS Equipment Engineering to Evaporator Project, which occurs upon the release of this document.

\subsection{ACCEPTANCE FOR BENEFICIAL USE (ABU) DOCUMENTATION}

The following list identifies the Acceptance for Beneficial Use (ABU) documentation which allows turnover of the Aw tank inlet air control stations from TWRS Equipment Engineering to Evaporator Project.

\section{Engineering Task Plan}

WHC-SD-WM-ETP-141, Engineering Task Plan for 241-AW Ventilation

Improvements, Rev 0 (released 8/22/95), Rev 1 (released 10/27/95)

\section{Safety Equipment List Changes}

Engineering Change Notice (ECN) 604846 to WHC-SD-WM-SEL-026, Double Shell Tank Interim Safety Equipment List, Rev 1 (ECN released $10 / 27 / 95$ )

Unreviewed Safety Question (USO) Screenings/Evaluations

USQ Evaluation TF-95-0083, AW Tank Farm Air Flow Control Assembly Installation, Operation, and Maintenance, (dated 8/31/95)

USQ Evaluation TF-95-0041, AW Tank HEPA-Filtered Air Inlet Station Installation, Operation, and Maintenance, Rev 0 (dated 8/31/95), Rev 1 (dated 10/13/95), Rev 2 (dated $4 / 11 / 96$ ), Rev 3 (dated $5 / 21 / 96)$ 
USQ Screening TF-96-0012, Pressure Decay Test for AW Air Inlet Station Filter Housing/Duct Assemblies, (dated 2/8/96)

USQ Screening TF-96-0083, Operational Test Procedure (OTP) for 241-AW Tank Inlet Air Control Stations, (dated 3/21/96)

\section{Interim Safety Basis/Safety Analysis Report Changes}

Engineering Change Notice (ECN) 631718 to WHC-SD-WM-ISB-001, Hanford Site Tank Farm Facilities Interim Safety Basis, Volume 2: Design Description, Rev 0-J, and WHC-SD-WM-SAR-016, Double Shell Tank Safety Analysis, Rev l (ECN released 6/27/96)

\section{Desian Bases Documents}

WHC-SD-WM-DB-030, Design Basis for Inlet Filters and Flow Control Devices in 241-AW Tank Farm, Rev 0 (released 9/12/95)

\section{Acceptance Test Procedures/Reports (ATP/ATR)}

WHC-SD-WM-ATP-154, Acceptance Test Procedure, Flow Controller and Vacuum Breaker Assemblies, Rev 1 (released 1/16/96)

WHC-SD-WM-ATR-154, Acceptance Test Report, Flow Controller and Vacuum Breaker Assemblies, Rev 0 (released 2/6/96)

Job Control System work package 2E-96-00103/M, Pressure Decay Test - AW Air Inlet Station Housing/Duct Assemblies, TWRS East Tank Farms

WHC-SD-WM-ATR-169, Acceptance Test Report, 241-AW Air Inlet Filter Station Pressure Decay Test, Rev 0 (released 2/21/96)

\section{Operational Test Procedures/Reports (OTP/OTR)}

WHC-SD-WM-0TP-195, Operational Test Procedure for 241-AW Tank

Inlet Air Control Stations, Rev 0 (released 2/20/96)

WHC-SD-WM-0TR-195, Operational Test Report for 241-AW Tank Inlet Air Control Stations, Rev 0 (released 7/3/96)

\section{Stress/Seismic/Design Analyses}

WHC-SD-WM-DA-210, 241AW Air Intake System Analysis, Rev 0 (released $1 / 25 / 96$ ) 
WHC-SD-WM-ABU-017

Rev 0

Page 7

\section{Final Design Drawings and Engineering Change Notices (ECNs)}

Drawing H-2-85614, HEPA Filtered Inlet, Rev 0 (released 12/13/95) with supplemental ECNs 624508, 624511, 624512, 624514, 624515, 624518

Drawing H-2-85608, Airflow Controller, Rev 0 (released 12/13/95) with supplemental ECNs 624509,624510,624523

Installation Drawings and/or Engineering Change Notices (ECNs)

ECN 614867 against $\mathrm{H}-2-70337$ to install concrete pads (ECN released $11 / 17 / 95)$

ECN 625020 against HVAC/vent piping drawing $\mathrm{H}-2-70337$ to instal1

air control stations/piping (ECN released $12 / 13 / 95$ )

ECN 624519 against dome penetration schedule drawing $\mathrm{H}-14-010502$ Sheet 2 (ECN released $2 / 27 / 96$ )

ECN 624513 against flow diagram H-2-70336 (ECN released $1 / 22 / 96$ ), air control station component diagram al so incorporated into drawing H-14-020102, Ventilation Tank Primary System (VTP) 0 \& M System $P$ \& ID (released 4/96)

Validation and Verification Records (besides ATRs and OTR)

Independent Design Review checklist documented in installation ECN 625020 (released 12/13/95)

WHC-SD-WM-TRP-247, Test Report, Constant Air Flow Control Device for 241-AW Tank Farm, Rev 0 (released 12/18/95)

QC/QA material and fabrication verifications and shop test data sheets evidenced in Job Control System work packages $2 \mathrm{H}-9500917 / \mathrm{F}$ and $2 \mathrm{H}-950103 \mathrm{l} / \mathrm{F}$

The Certificate of Conformance for the HEPA filters and housings, and HEPA filter test data (for tests performed prior to delivery), are archived as quality records under purchase order WBJ-XDV-388581

\section{Training to Operating Crews}

Operator continuing training given to shifts $A, B, C, D$, and $T$ between $4 / 10 / 96$ and $5 / 1 / 96$ (cycle 96-7), incorporating training bullet in \#TRP-2.A.16, AW Inlet Ventilation Upgrade. 


\section{Operating Procedures}

Procedure Change Authorization ETF-96-081 to Tank Farm Plant Operating Procedure T0-060-104, Operate the 241-AW Primary Tank Ventilation System, revised 3/27/96

Procedure Change Authorization 242-A-96-076 to Tank Farm Operator Round Sheets TF-0R-A-03, AP, AW Tank Farms and LERF, revised $4 / 01 / 96$

Procedure Change Authorizations ETF-96-074 through -079 to Tank Farm Alarm Response Procedures ARP-T-231-00101 through -00196, Respond to Panel Alarms at $271-A W$, revised $3 / 22 / 96$

\section{Surveillance Procedures}

Given the simplicity of the air control station design, the revisions to the ventilation system operating procedure and operator round sheets (above) provide sufficient detail to perform the necessary surveillance activities. Thus, no actual

Surveillance Procedures, as such, were needed.

\section{Preventative Maintenance Procedures}

Revision 0 Change 0 to 6-TF-156, Waste Tank Plant Maintenance, Appendix TW, 241-AW Tank Inlet Filter Aerosol Test Data Sheets, revised $3 / 27 / 96$

NOTE: Given the simplicity of the air control station design, there are no expected preventative maintenance needs which are not already addressed via existing operating and maintenance procedures (above) and planned periodic testing and calibration of station components (below). Thus, no actual Preventive Maintenance Procedures, as such, were needed.

\section{CBRS (PM/S) Data Sheets}

All differential pressure gages and HEPA filters on the air control stations have been set up in the Job Control System (JCS) for periodic calibration or testing. See drawing H-14-020102, Ventilation Tank Primary System (VIP) 0 \& M System $P$ \& ID, for component numbers.

\section{Vendor Information File}

Except for a few standard components, the air control stations were designed and fabricated on-site. The crucial tests on the final assemblies were performed on-site. Released design media, testing reports and validation records (above) adequately document 
pertinent material and equipment information. There is no remaining vendor information which is significant enough to warrant the expense of generating and maintaining a separate vendor information file.

\section{Spare Parts List}

A recommended spare parts 1 ist is shown on drawing $\mathrm{H}-2-85614$, HEPA Filtered Inlet, Sheet 2

\section{Spare Parts In Stock}

Spare pre-filters and HEPA filters were ordered under Purchase Requisitions 451201 and 462969 , respectively. The pre-filters will be stored in the $2101 \mathrm{M}$ warehouse (200E Area). The HEPA filters are stored in $2101 \mathrm{M}$ convenient storage under stock number $7900-4629-6901$.

A spare vacuum breaker and air flow controller were built under fabrication work package $2 \mathrm{H}-950103 \mathrm{l} / \mathrm{F}$ and are stored in $210 \mathrm{MM}$ (200E Area) convenient storage as stock number 9900-4269-0001.

\subsection{CONCLUSIONS}

The air control stations meet the functional requirements for flow (settable from 50 to $500 \mathrm{cfm}$ ), tank vacuum (allow tanks to remain within the operating range of -0.5 to -4 IN WG), and accuracy $(+/-10 \%)$ as specified in WHC-SD-WM-DB-030, Design Basis for Inlet Filters and Flow Control Devices in 241-AW Tank Farm, Rev 0 .

As reported in WHC-SD-WM-OTR-195, Operational Test Report for 241-AW Tank Inlet Air Control Stations, Rev 0, with all six air flow controllers set between 70 and $125 \mathrm{cfm}$, tank vacuum levels remained at approximately 1.5 IN WG. The OTR also reported that unidentified sources of tank air inleakage still exist, and recommended that attempts be made to locate and further reduce this inleakage to allow full benefit of the air control stations' capabilities (i.e., allow higher vacuum levels and/or higher flow settings). As a result of the currently achieved tank vacuum levels, an operational problem (i.e., low tank vacuum) may occur during tank farm/evaporator transfer operations. As reported in the OTR, however, isolating one or more of the air control stations (i.e., to increase tank vacuum) prior to transfer activities will reduce the magnitude of this problem by allowing the primary ventilation system to operate closer to its full capabilities. 
WHC-SD-WM-ABU-017

Rev 0

Page 10

\section{APPENDIX A}

\section{ACCEPTANCE FOR BENEFICIAL USE CHECKLIST} (FROM WHC-SD-WM-ETP-141 REV 1) 


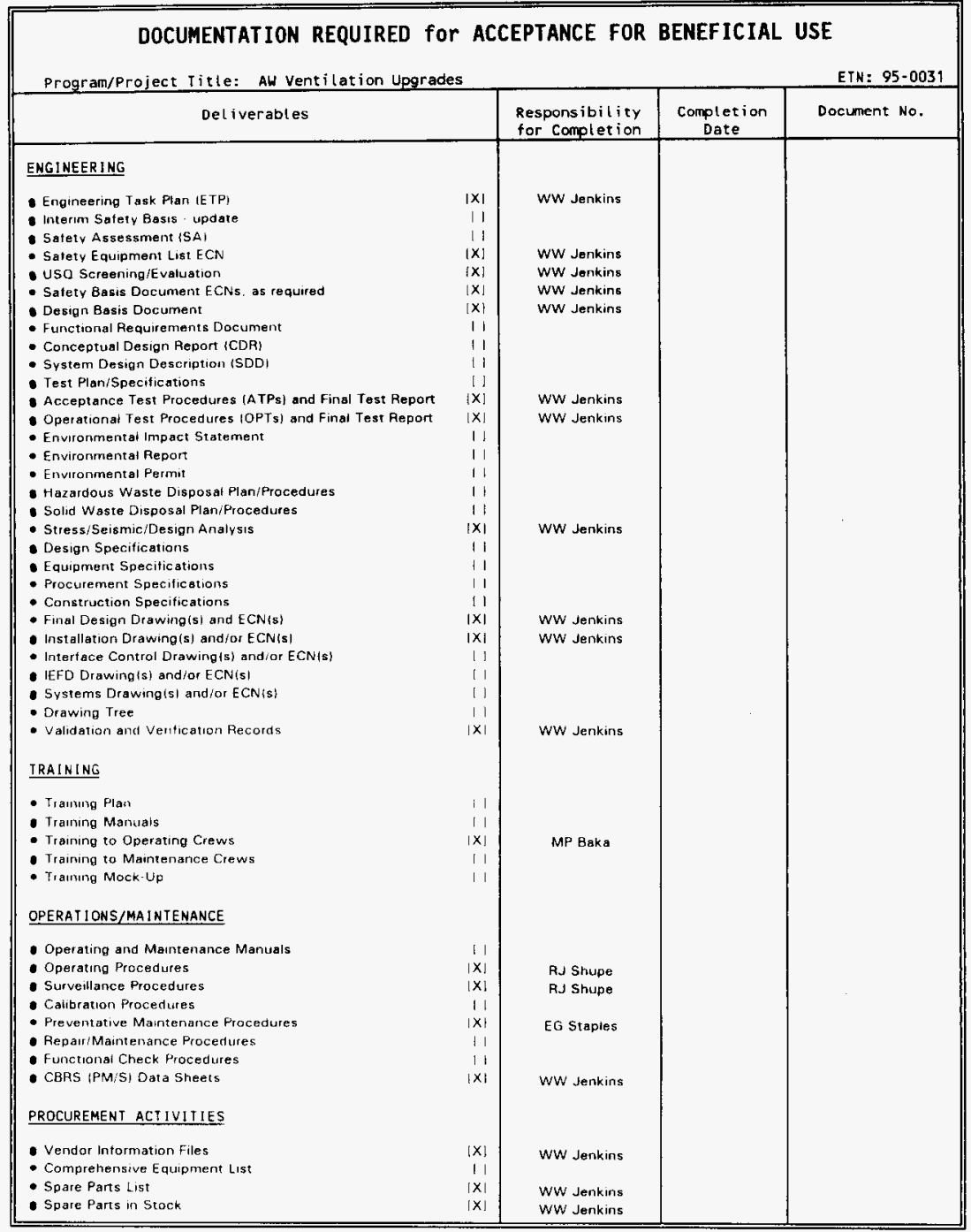




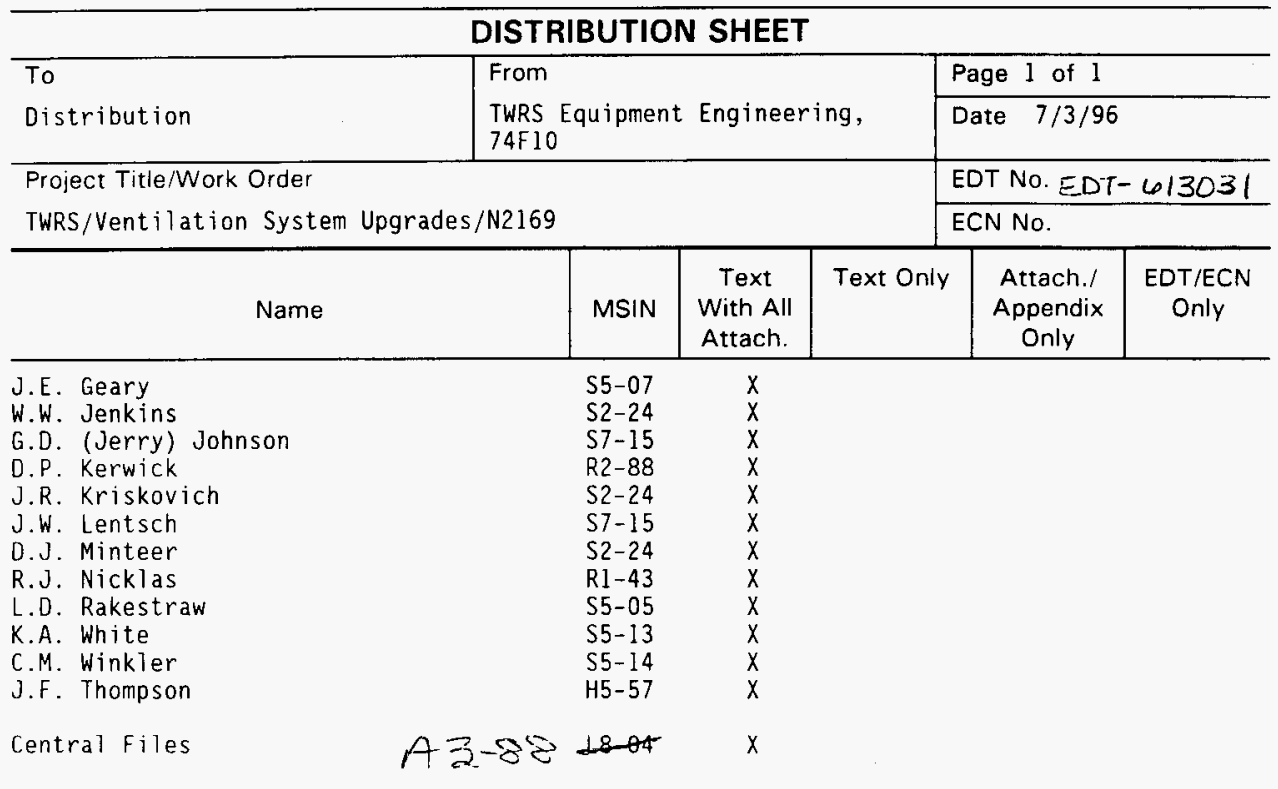

